\title{
EFFECTS OF DIFFERENT VOLUMES OF RESISTANCE EXERCISE ON THE FOOD INTAKE OF RATS
}

\section{EFEITOSDEDIFERENTES VOLUMES DEEXERCICIO DERESISTÊNCIA SOBRE OCONSUMO ALIMENTARDERATOS}

\author{
EFECTOS DE DIFERENTES VOLÚMENES DEEJERCICIO DE RESISTENCIA SOBREEL CONSUMO
} ALIMENTARIO DERATAS

\author{
Ramires Alsamir Tibana ${ }^{1,2}$ \\ (Physical Education Professional) \\ Ivo Vieira de Sousa Neto² \\ (Physical Education Professional) \\ Nuno Manuel Frade de Sousa ${ }^{3}$ \\ (Physical Education Professional) \\ Felipe Carneiro $\mathrm{Krier}^{2}$ \\ (Medicine Undergraduate) \\ Jeeser Alves de Almeida ${ }^{4}$ \\ (Physical Education Professional) \\ Jonato Prestes ${ }^{2}$ \\ (Physical Education Professional) \\ Fabrício Azevedo Voltarelli ${ }^{1}$ \\ (Physical Education Professional)
}

\section{Universidade Federal de Mato Grosso, Faculdade de Educação Física, MT, Brazil. \\ 2. Universidade Católica de Brasília, Programa de Pós-Graduação Stricto Sensu em Educação Física, DF, Brazil. 3. Faculdade Estácio de Sá de Vitória, Faculdade de Educação Física, Laboratório de Fisiologia do Exercício e Medidas e Avaliação, ES, Brazil. \\ 4. Universidade Federal de Mato Grosso do Sul, Faculdade de Educação Física, MS, Brazil.}

\section{Correspondence:}

Programa de Pós Graduação Stricto Sensu em Educação Física, Universidade Católica de Brasília. Q.S. 07, Lote 01 - Bloco G, Águas Claras, Taguatinga, Brasília, DF, Brazil. 71966-700. ramiires@hotmail.com

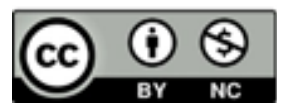

\begin{abstract}
Introduction: Physical exercise changes food intake after an acute session; however further research is needed to identify the effects of resistance exercise (RE) with different training volumes. Objective: To investigate the effects of acute RE (two sessions) with different training volumes on the food intake of rats. Methods: Twenty four Wistar rats were randomly divided into three groups: control group (who did not perform RE; $n=8$ ); RE (stair climbing) with four series $(\mathrm{G} 4, \mathrm{n}=8)$ and overload of $50 \%, 75 \%, 90 \%$, and $100 \%$ of the maximum load capacity of the animal and RE with eight series (G8; $n=8)$ with two increases of each overload of $50 \%, 75 \%, 90 \%$, and $100 \%$ of the maximum load capacity of the animal. The average amount of ingested feed was measured for each experimental group 24 and 48 hours after the first RE session and 72 hours after the second RE session. Results: The food intake of the groups that performed the RE session was significantly lower $(p<0.05)$ when compared to the control group only at 24 hours after the first training session. After the second training session (72 h), the G8 showed a significantly lower food intake $(p<0.05)$ when compared to $G 4$ and the control group. However, the food consumption relative to the body mass of the animals ( $/ \mathrm{gBM}$ ) was significantly lower only after the second training session ( $72 \mathrm{~h}$ ) in $\mathrm{G} 8$ ( $p<0.05)$ compared to $\mathrm{G} 4$ and the control group. Conclusion: Therefore, the resistance exercise decreases the food intake of rats after an acute session; in addition, a higher training volume seems to be more advantageous. Level of Evidence ll; Therapeutic studies - Investigation of treatment results.
\end{abstract}

Keywords: Obesity; Resistance training; Food intake.

\section{RESUMO}

Introdução: O exercício físico altera o consumo alimentar nas horas subsequentes a uma sessão aguda; no entanto, são necessárias novas investigações com o propósito de identificar os efeitos do exercício de resistência (ER) realizado com diferentes volumes de treinamento. Objetivo: Investigar os efeitos do ER agudo (duas sessöes) com diferentes volumes de treinamento sobre o consumo alimentar de ratos. Métodos: Foram utilizados vinte e quatro ratos Wistar, divididos aleatoriamente em três grupos: grupo controle (que não realizaram $E R ; n=8$ ); $E R$ (escaladas na escada) com quatro séries (G4; $n=8$ ) e sobrecarga de 50\%, 75\%, 90\% e 100\% da capacidade máxima de carga do animal e ER com oito séries (G8; $n=8)$ com duas elevações de cada sobrecarga de 50\%, 75\%, 90\% e 100\% da capacidade máxima de carga do animal. A quantidade média de ração ingerida foi medida para cada grupo experimental 24 e 48 horas após a primeira sessão de ERe 72 horas após a segunda sessão de ER. Resultados: O consumo alimentar dos grupos que realizaram a sessão de ER foi significativamente menor $(p<0,05)$ quando comparado ao grupo controle apenas nas 24 horas após a primeira sessão de treinamento. Após a segunda sessão de treinamento (72 h), o G8 apresentou um consumo alimentar significativamente menor ( $p<0,05)$ quando comparado ao G4 e ao grupo controle. Entretanto, o consumo alimentar relativo à massa corporal dos animais (g/gMC) foi significativamente menor apenas após a segunda sessão de treinamento (72 h) no G8 ( $p<0,05)$ comparado com o G4 e o grupo controle. Conclusão: Assim sendo, o exercício de resistência diminui a ingestão alimentar de ratos após uma sessão aguda, além disso, um maior volume de treino parece ser mais vantajoso. Nível de evidência ll; Estudos terapêuticos - Investigação dos resultados do tratamento.

Descritores: Obesidade; Treinamento de resistência; Ingestão alimentar.

\section{RESUMEN}

Introducción: El ejercicio físico altera el consumo de alimentos en las horas posteriores a una sesión aguda; sin embargo, son necesarias nuevas investigaciones con el propósito de identificar los efectos del ejercicio de resistencia (ER) realizado con diferentes volúmenes de entrenamiento. Objetivo: Investigar los efectos del ER agudo (dos sesiones) con diferentes volúmenes deentrenamiento sobre el consumo alimentario de ratas. Métodos: Se utilizaron 24 ratas Wistar, divididas aleatoriamenteen tres grupos: grupo control (que no realizaron $E R ; n=8$ ); $E R$ (subidas en la escalera) con cuatro series ( $(G 4, n=8)$ y sobrecarga de $50 \%, 75 \%, 90 \%$ y 100\% de la capacidad máxima de carga del animal y ER con ocho series $(G 8 ; n=8)$ con dos elevaciones de cada sobrecarga del 50\%, 75\%, 90\% y 100\% de la capacidad máxima de carga del animal. La cantidad promedio de ración ingerida se midió para cada grupo experimental 24 y 48 horas después de la primera sesión de ER y 72 horas después de la segunda sesión. Resultados: El consumo de alimentos de los grupos quellevaron a cabo la sesión de ER fue significativamente menor ( $p<0,05)$ en comparación con el grupo control sólo en las 24 horas después de la primera sesión de entrenamiento. 
Después de la segunda sesión de entrenamiento (72 h), el G8 presentó un consumo alimentario significativamente menor $(p<0,05)$ en comparación con el G4 y el grupo control. Sin embargo, la ingesta de alimentos relativa a la masa corporal de los animales (g/gMC) fue significativamente menor sólo después de la segunda sesión de entrenamiento (72 h) en el G8 $(p<0,05)$ en comparación con el G4 y el grupo control. Conclusión: Por lo tanto, el ejercicio de resistencia disminuye la ingesta de alimentos de ratas después de la sesión aguda; además, un mayor volumen de entrenamiento parece ser más ventajoso.

Nivel de Evidencia ll; Estudios terapéuticos - Investigación de los resultados del tratamiento.

Descriptores: Obesidad; Entrenamiento de resistencia; Ingestión de alimentos.

\section{INTRODUCTION}

Obesity rates have been rising alarmingly in most countries, reaching more than one billion people worldwide. According to the World Health Organization (WHO), obesity is a chronic disease of epidemic proportions that affects children, adolescents and adults in countries with different levels of development, and even surpasses malnutrition and infectious diseases. This global epidemic requires special attention from the health services, since by 2015 , an estimated two billion three hundred thousand individuals will be overweight and more than seven hundred million will be obese. In this context, body mass regulation is crucially important, as excess adiposity is directly related to several pathologies, such as type II diabetes, hypertension, dyslipidemia, cancer, cardiovascular diseases and early mortality. ${ }^{2}$

Body mass is a result of the balance between caloric intake and expenditure, while physical exercise is one of the most effective ways of increasing energy expenditure. ${ }^{3}$ It has been proposed that physical activity not only contributes to a negative energy balance by increasing energy expenditure, but also brings about changes in appetite and reduces food intake. ${ }^{4}$ Complex regulation of food intake through physical activity depends on the integration of the central region and on peripheral neurohormonal signaling. ${ }^{5}$ In addition, the impact of physical activity on appetite control shows considerable variability, depending on type (aerobic and resistance), duration of the session and length of exercise intervention (acute and chronic). ${ }^{6-9}$

Therefore, circulating levels of some hormones and cytokines can be modified in response to exercise, possibly affecting appetite control. ${ }^{9}$ Broom et al. ${ }^{6}$ recently analyzed the influence of an acute session of aerobic exercise (60 minutes of running on the treadmill at $70 \%$ of maximal oxygen consumption) and resistance exercise (10 full-body workouts, 3 sets of 12 repetitions) on the perception of hunger, circulating concentrations in appetite-regulating hormones (acylated ghrelin, insulin and peptide tyrosine tyrosine) and dietary intakes of healthy men. The authors reported lower concentrations of acylated ghrelin in both protocols (aerobic and resistance) when compared to the control session. On the other hand, circulating concentrations of the peptide tyrosine tyrosine (PYY) were elevated only after the aerobic exercise session. The authors also reported suppression of hunger after the exercise models when compared to the control group. Similarly, Ballard et al. ${ }^{7}$ demonstrated in healthy young men that resistance exercise was able to decrease plasma ghrelin during and after exercise, and that this decrease was associated with lower post-exercise relative food intake.

Nevertheless, studies with animals submitted to different exercise protocols point to an improvement in the sensitivity of the receptor for leptin and for insulin in the hypothalamus in comparison to sedentary animals. ${ }^{10}$ Another aspect that is no less important is the production of anti-inflammatory cytokines promoted by exercise, especially interleukins (ILs) IL-6 and IL-10, both acting on the hypothalamus so as to improve insulin and leptin signaling. ${ }^{11}$

It is clear in the literature that exercise is able to reduce and/or not alter dietary intake in the hours following an acute session; ${ }^{7-8}$ however, further investigations are necessary to identify the effects of RE performed with different training volumes. In addition, animal studies are needed, since in humans there are several problems involved in quantifying food intake control. For example, self-reported food intake measures (24-hour dietary recall, food frequency questionnaire, and dietary records or food diaries) are notoriously inaccurate. ${ }^{12}$

Therefore, the objective of this study was to analyze the effects of acute RE in different training volumes on the dietary intake of rats. The hypothesis of this study was that both resistance exercise models would be effective in reducing food intake, with better results for the group with higher training volume.

\section{MATERIALS AND METHODS}

All the experiments were conducted according to the principles and procedures of care with the use of experimental animals, and were approved by the Animal Research Institutional Review Board of Universidade Católica de Brasília, protocol No. (10/2013). The experiments were carried out in the first half of 2014. Twenty-four $(n=24)$ four-month-old Wistar rats were obtained from the central vivarium of Universidade Católica de Brasilia for use in the study. The animals were housed in cages containing four animals each, and received water and standard rodent feed during the experimental period, ad libitum. The rats were exposed to 12 -hour light/dark cycles and kept at a temperature of $20^{\circ} \mathrm{C}$ to $22^{\circ} \mathrm{C}$. The normocaloric diet consisted of commercial rodent feed (Purina ${ }^{\oplus}$, Descalvado-SP, Brazil), with the following composition of macronutrients: $58.72 \%$ carbohydrates, $32.23 \%$ protein, and $9.06 \%$ lipids, totaling $3.2 \mathrm{Kcal} / \mathrm{g}$. The animals were randomly divided into three subgroups: control group ( $n=8)$, which did not perform any exercise; $(n=8)$, series 4 group ( $n=8)$, which climbed the ladder four times (G4), and series eight group ( $n=8)$, which climbed the ladder eight times (G8).

The rats were initially adapted to the resistance exercise protocol, which required the animals to climb a vertical ladder (1.1 x 0.18 m, 2-cm step, 80\% climbing angle) with weights attached to their tails (Figure 1). The size of the ladder caused the animals to perform 8-12 movements per climb. The loading apparatus was secured to the proximal portion of the tail with a self-adhesive tape. With the apparatus fixed to their tails, the rats were placed at the bottom of the ladder and familiarized with the ladder. If necessary, a stimulus was applied to the animal's tail using tweezers to initiate movement. At the top of the ladder, the rats reached a cage $(20 \times 20 \times 20 \mathrm{~cm})$ where they rested for approximately $120 \mathrm{~s}$. This procedure was repeated until the animals could voluntarily climb the subsequent series without stimulation.

Three days after this familiarization, the determination of maximum loading capacity consisted of 4-8 ladder climbs with progressively heavier loads. The initial climb consisted of carrying a load corresponding to $75 \%$ of the animal's body weight. After this, a weight of $30 \mathrm{~g}$ was progressively added up to the point where the rat was unable to climb the entire ladder. Failure to climb was determined when the animal was unable to progress up the ladder after three successive tail stimuli. The highest load carried up to the top of the ladder was considered the rat's maximum loading capacity for that particular training session. 


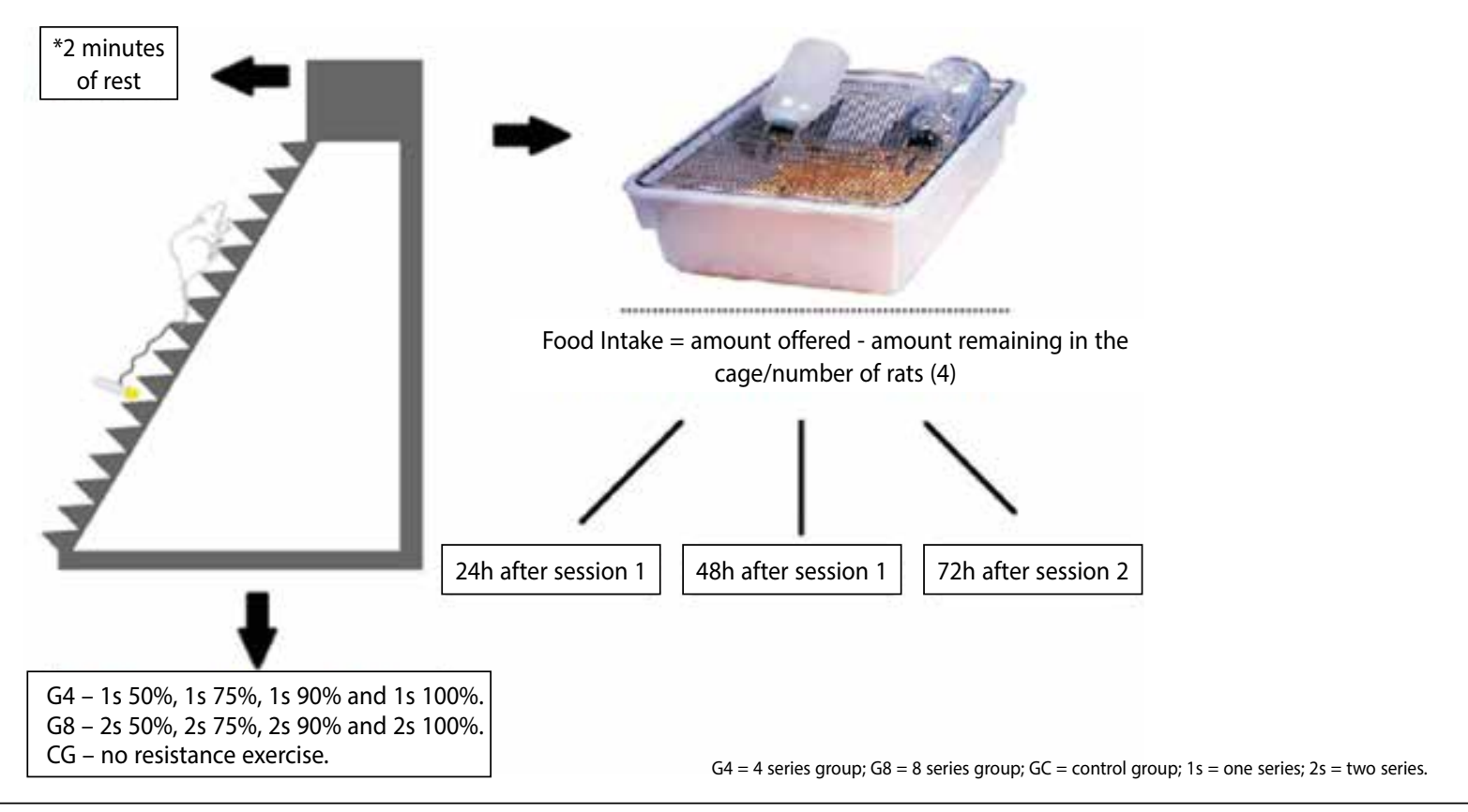

Figure 1. Experimental design of the study.

Once the maximum loading capacity was determined, the training sessions consisted of four climbs (G4) with 50\%,75\%, 90\%, and 100\% and eight climbs (G8) with two series of each load at 50\%, 75\%, 90\%, and $100 \%$ of the animal's maximum loading capacity. The resistance exercise protocol was adapted from Prestes et al., 2012.".

The average amount of feed consumed was measured for each experimental group $24 \mathrm{~h}$ and $48 \mathrm{~h}$ after the first RE session and $72 \mathrm{~h}$ after the second RE session. Five hundred grams of feed were offered shortly after the acute RE sessions in each cage, with quantification performed using the equation: average intake $=$ (amount offered - amount remaining in the cage)/number of animals in the box.

\section{Statistical analysis}

Data are presented in mean \pm standard deviation (SD). The comparison of body mass and dietary intake among the three groups at the different timepoints was performed using the nonparametric Kruskal-Wallis H test. The software used was SPSS version 20.0 (Somers, NY, USA) with significance level of $p \leq 0.05$.

\section{RESULTS}

Body mass at the start of the training sessions was $370.6 \pm 38.4 \mathrm{~g}$ for the control group, $359.8 \pm 45.5 \mathrm{~g}$ for $\mathrm{G} 4$, and $363.4 \pm 36.0 \mathrm{~g}$ for $\mathrm{G} 8$, with no statistically significant differences $(p=0.860)$ between them. The maximum loading capacity was $557.8 \pm 24.8 \mathrm{~g}$ for $\mathrm{G} 8$ and $557.7 \pm 37.0 \mathrm{~g}$ for $\mathrm{G} 4$, without statistically significant differences $(p=0.993)$ between them.

Figure 2 shows the animals' food intake $24 \mathrm{~h}$ and $48 \mathrm{~h}$ after the first training session and $72 \mathrm{~h}$ after the second training session. The food intake of the groups that performed the training session was significantly lower $(p<0.05)$ than the control group just $24 \mathrm{~h}$ after the first training session. After the second training session (72h), G8 had significantly lower food intake ( $p<0.05$ ) than $\mathrm{G} 4$ and the control group. Considering the total analysis time, the control group had a significantly higher food intake ( $p$ $<0.05)$ than the two training groups $(104.1 \pm 0.7 \mathrm{~g}$ control group versus $101.4 \pm 3.9 \mathrm{~g} \mathrm{G} 4$ and $95.1 \pm \pm 0.9 \mathrm{~g} \mathrm{G} 8$.

Figure 3 shows food intake relative to the animals' body mass ( $\mathrm{g} /$ gMC) $24 \mathrm{~h}$ and $48 \mathrm{~h}$ after the first training session and $72 \mathrm{~h}$ after the second training session. Statistically significant differences were only observed after the second training session (72h), and G8 had a food

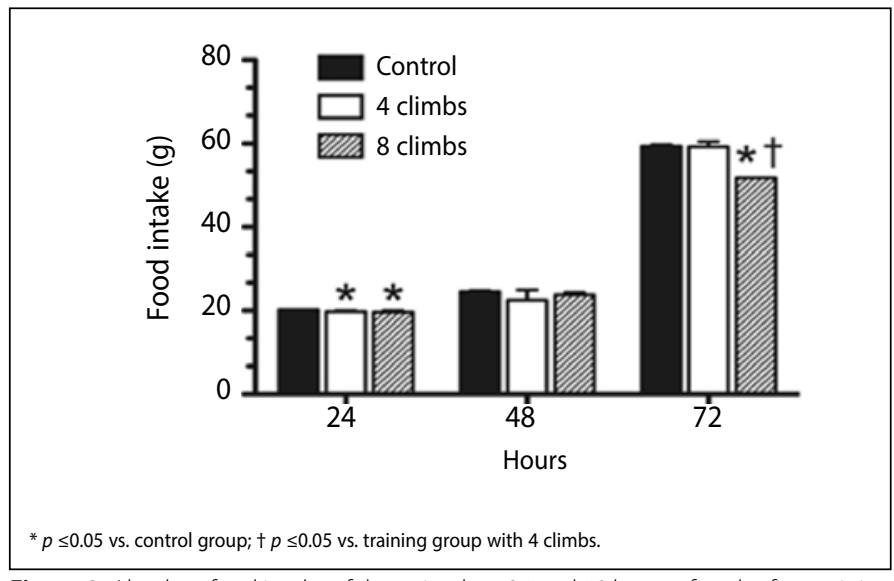

Figure 2. Absolute food intake of the animals at 24 and 48 hours after the first training session and 72 hours after the second training session.

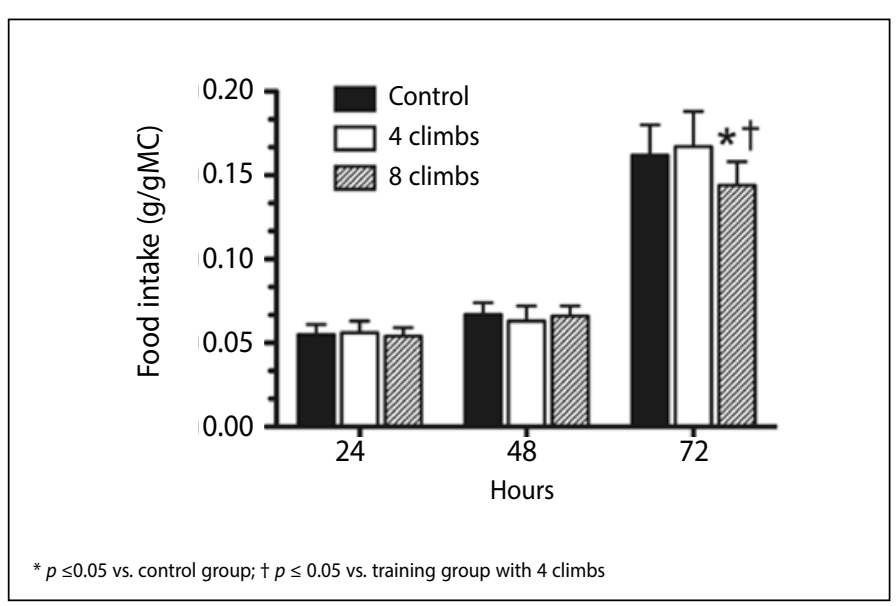

Figure 3. Food intake consumption relative to the animals' body mass at 24 and 48 hours after the first training session and 72 hours after the second training session.

intake corrected for body mass that was significantly lower $(p<0.05)$ than $\mathrm{G} 4$ and the control group. There were no statistically significant differences $(p>0.05)$ in food intake corrected for body mass considering the sum of all the analysis times $(0.284 \pm 0.014 \mathrm{~g} / \mathrm{gMC}$ control group, $0.286 \pm 0.036 \mathrm{~g} / \mathrm{gMC}$ G4, $0.264 \pm 0.025 \mathrm{~g} / \mathrm{gMC}$ G8). 


\section{DISCUSSION}

The objective of this study was to analyze the effects of acute RE with different training volumes on the dietary intake of rats. Confirming the initial hypothesis, food intake of the groups that performed RE was lower than in the control group. In addition, the group that performed a higher volume of training achieved lower food intake over 72 hours after the second training session.

It is well established that RE can increase muscle mass, strength and power. ${ }^{13}$ Moreover, studies indicate the association of muscle strength with the decrease of cardiovascular risk factors, insulin resistance, obesity and high blood pressure, metabolic syndrome and early death. ${ }^{14}$ And more recently, studies have shown that an acute RE session may decrease ${ }^{7}$ or not alter ${ }^{8}$ food intake in healthy individuals.

To the best of our knowledge, this is the first study to analyze the effect of different volumes of RE (G4 versus G8) on the dietary intake of rats. Previous studies have demonstrated that both exercise models (aerobic and RE) promoted a decrease and/or did not alter food intake in the hours following acute exercise, both in the healthy population and in overweight/obese patients. ${ }^{6-9,15}$ For example, Martins et al. ${ }^{15}$ analyzed the effects of an acute session of aerobic exercise performed at different intensities (moderate intensity continuous, high intensity and short duration high intensity) on the hormones acylated ghrelin, PYY and glucagon-like peptide 1, and appetite sensation in overweight/ obese individuals. The authors reported that the glucagon-like peptide 1 (GLP-1) was increased after all the exercise sessions, yet acylated ghrelin was decreased only in the moderate and high intensity sessions, but not in the high intensity short duration session, which could induce a decrease in food intake after exercise, especially in high intensity exercises. However, no reductions in caloric intake were observed.

In a recent meta-analysis developed by Schubert et al., ${ }^{9}$ the authors analyzed the impact of acute aerobic exercise and RE on food intake. The authors suggested that although absolute food intake does not decline after acute exercise, the energy expenditure created by exercise is not offset by a change in energy consumption, and that such a deficit may have significant implications for body mass control.

Studies have shown that anorexigenic gastrointestinal hormones (GLP-1 and PYY) are increased after an acute exercise session, and the orexigenic gastrointestinal hormone ghrelin may decrease after an acute session. ${ }^{4}$ In addition, it is known that an acute RE session may increase the production of anti-inflammatory cytokines (IL-6 and IL-10), which can enhance and potentiate the signaling of insulin and leptin with their respective receptors in the hypothalamus. ${ }^{11}$ In this study, the group with highest training volume had lower food intake during the hours following the exercise when compared to training with lower volume (lower food intake only in the first 24 hours post-exercise). It is possible that a higher training volume may have a greater influence on the increase of the release of anorexigenic hormones (GLP-1, PYY) and/or the decrease of the orexigenic hormone (ghrelin), besides the greater production of anti-inflammatory cytokines which may potentiate the action of insulin and leptin, promoting a decrease in appetite. Mechanisms related to decreased food intake in rats after an acute RE session were not analyzed in this study.

\section{CONCLUSIONS}

Lastly, the results of this study demonstrated that resistance exercise with different volumes ( $G 4$ and $G 8$ ) induces suppression of food intake compared to the control group over the initial 24 hours after the first session. However, a higher training volume (G8) was more effective in reducing food intake when compared to the group with lower volume (G4) and the control group. In this regard, RE may be a good way to control food intake, which may benefit the treatment of obesity. In addition, despite the greater metaboliclenergy stress of higher volume training, food intake was lower, factors which may contribute to the loss and control of body mass. It is suggested that future studies analyze the chronic effects of RE with different volumes on dietary intake, body mass, fat stores, and the mechanisms underlying these processes.

\section{ACKNOWLEDGMENTS}

The authors would like to thank the laboratory technician for her assistance in the experiments. They are also grateful for the financial support of PIBIC/CNPQ, CAPES/PROSUP, without which this research would not have been completed.

All authors declare no potential conflict of interest related to this article.

AUTHORS' CONTRIBUTIONS: Each author made significant individual contributions to this manuscript. RAT (0000-0003-0124-0826)*, IVSN (0000-0002-1479-5866)*, FAV (0000-0002-8077-8941)*, JP (0000-0003-0399-8817)*: were the main contributors in the writing of the manuscript; RAT, IVSN, FAV, FCK (0000-0003-0537-1321)*: carried out the experimental part; NMFS (0000-0001-5854-616X)*, JAA (0000-0002-3409-8005)*: participated in the data analysis; RAT, IVSN, FAV, NMFS, FCK, JAA, JP, participated actively in the discussion of results, review and approval of the final version of the article. ${ }^{*} \mathrm{ORCID}$ (Open Researcher and Contributor ID).

\section{REFERENCES}

1. World Health Organization Fact sheet: obesity and overweight. Available online: http://www.who.int/ mediacentre/factsheets/fs311/en/

2. DeMarco VG, Aroor AR, Sowers JR. The pathophysiology of hypertension in patients with obesity. Nat Rev Endocrinol. 2014;10(6):364-76.

3. Donnelly JE, Blair SN, Jakicic JM, Manore MM, Rankin JW, Smith BK, et al. American College of Sports Medicine Position Stand. Appropriate physical activity intervention strategies for weight loss and prevention of weight regain for adults. Med Sci Sports Exerc. 2009;41(2):459-71. Erratum in: Med Sci Sports Exerc. 2009;41(7):1532.

4. Schubert MM, Desbrow B, Sabapathy S, Leveritt M. Acute exercise and subsequent energy intake. A meta-analysis. Appetite. 2013;63:92-104.

5. Morton GJ, Meek TH, Schwartz MW. Neurobiology of food intake in health and disease. Nat Rev Neurosci. 2014;15(6):367-78.

6. Broom DR, Batterham RL, King JA, Stensel DJ. Influence of resistance and aerobic exercise on hunger, circulating levels of acylated ghrelin, and peptide YY in healthy males. Am J Physiol Regul Integr Comp Physiol. 2009;296(1):R29-R35.

7. Ballard TP, Melby CL, Camus H, Cianciulli M, Pitts J, Schmidt S, et al. Effect of resistance exercise, with or without carbohydrate supplementation, on plasma ghrelin concentrations and postexercise hunger and food intake. Metabolism. 2009;58(8):1191-9.
8. Cadieux S, McNeil J, Lapierre MP, Riou MĖ, Doucet E. Resistance and aerobic exercises do not affect postexercise energy compensation in normal weight men and women. Physiol Behav. 2014;130:113-19.

9. Schubert MM, Sabapathy S, Leveritt M, Desbrow B. Acute exercise and hormones related to appetite regulation: a meta-analysis. Sports Med 2014;44(3):387-403.

10. Flores MB, Fernandes MF, Ropelle ER, Faria MC, Ueno M, Velloso LA, et al. Exercise improves insulin and leptin sensitivity in hypothalamus of Wistar rats. Diabetes. 2006;55(9):2554-61.

11. Ropelle ER, Flores MB, Cintra DE, Rocha GZ, Pauli JR, Morari J, et al. IL-6 and IL-10 anti-Inflammatory activity links exercise to hypothalamic insulin and leptin sensitivity through IKKß and ER Stress Inhibition. PLoS Biol. 2010;8(8):e1000465.

12. Schoeller DA, Thomas D, Archer E, Heymsfield SB, Blair SN, Goran, MI. et al. Self-report-based estimates of energy intake offer an inadequate basis for scientific conclusions. Am J Clin Nutr. 2013;97(6):1413-5

13. Prestes J, Leite RD, Pereira GB, Shiguemoto GE, Bernardes CF, Asano RY, et al. Resistance training and glycogen content in ovariectomized rats. Int J Sports Med. 2012;33(7):550-4.

14. Tibana RA, Prestes J. Treinamento de força e síndrome metabólica: uma revisão sistemática. Rev Bras Cardiol. 2013;26(1):66-76.

15. Martins C, Stensvold D, Finlayson G, Holst J, Wisloff U, Kulseng B, et al. Effect of moderate- and high-intensity acute exercise on appetite in obese individuals. Med Sci Sports Exerc. 2015;47(1):40-8. 